\title{
Application of butane geochemistry of natural gas in hydrocarbon exploration
}

\author{
Miao Zhongying, 2*, Chen Jianfa ${ }^{2}$, Wang Jing ${ }^{3}$, Wang Guannan², Zhang \\ $\mathrm{Chen}^{4}$ and Li Wei ${ }^{2}$ \\ ${ }^{1}$ Institute of Mineral Resources, Chinese Academy of Geological Sciences, Beijing 100037, China \\ ${ }^{2}$ State Key Laboratory of Petroleum Resources and Prospecting, China University of Petroleum, Beijing 102249, China \\ ${ }^{3}$ Luliang Oilfield Operation District, PetroChina Xinjiang Oilfield Company, Karamay, Xinjiang 834000, China \\ ${ }^{4}$ Department of Natural Gas, PetroChina Tarim Oilfield Company, Korla, Xinjiang 841000, China
}

(C) China University of Petroleum (Beijing) and Springer-Verlag Berlin Heidelberg 2012

\begin{abstract}
In order to distinguish the source and migration direction of natural gas by geochemical characteristics of butane, the components and carbon isotopes of natural gas from major hydrocarbonbearing basins in China were analyzed. The results showed that: (1) Oil-type gas has $i-\mathrm{C}_{4} / n-\mathrm{C}_{4}<0.8$, $\delta^{13} \mathrm{C}_{\text {butane }}<-28 \%$, $\delta^{13} \mathrm{C}_{i \text {-butane }}<-27 \%$, $\delta^{13} \mathrm{C}_{n \text {-butane }}<-28.5 \%$, whereas coal-type gas has $i-\mathrm{C}_{4} / n-\mathrm{C}_{4}>0.8$, $\delta^{13} \mathrm{C}_{\text {butane }}>-25.5 \%$ o, $\delta^{13} \mathrm{C}_{i \text {-butane }}>-24 \%$, $\delta^{13} \mathrm{C}_{n \text {-butane }}>-26 \%$. (2) When $\delta^{13} \mathrm{C}_{i \text {-butane }}-\delta^{13} \mathrm{C}_{n \text {-butane }}$ is greater than 0 , the maturity of oil-type gas is generally more than $2.4 \%$ and that of coal-type gas is greater than $1.4 \%$, whereas when the difference is less than 0 , the maturity of oil-type gas is generally less than $1.1 \%$ and that of coal-type gas is less than $0.8 \%$. (3) When natural gas migrates through dense cap rocks, the value of $i-\mathrm{C}_{4} / n-\mathrm{C}_{4}$ increases, whereas when it migrates laterally along a reservoir, the value of $i-\mathrm{C}_{4} / n-\mathrm{C}_{4}$ decreases. (4) Sapropelic transition zone gas with composition and carbon isotopic signatures similar to those of oil-type gas in the low thermal evolution stage is found to have a relatively high butane content. (5) The values of $i-\mathrm{C}_{4} / n-\mathrm{C}_{4}$ and $\delta^{13} \mathrm{C}_{n \text {-butane }}-\delta^{13} \mathrm{C}_{i \text {-butane }}$ of gas which has suffered biological degradation are significantly higher than those obtained from thermogenic and bio-thermocatalytic transition zone gas. Thus, natural gas of different genetic types can be recognized through component analysis and carbon isotopic signatures of butane, the natural gas maturity can be estimated from the difference in carbon isotopic content between isobutane and $n$-butane, and the migration direction of natural gas can be determined from $i-\mathrm{C}_{4} / n-\mathrm{C}_{4}$ ratios and transport conditions, which can also be used to thermogenic and bio-thermocatalytic transition zone gas.
\end{abstract}

Key words: Natural gas, $n$-butane, isobutane, carbon isotope, genetic types of natural gas, migration direction

\section{Introduction}

Natural gas is characterized by simple composition, multiple sources, complicated migration paths, and easy dissipation, which make it difficult to identify the origin, source, and migration direction of the natural gas, thus influencing our understanding of the natural gas accumulation. After many years of research, scientists in China have developed new theories of natural gas geology and novel exploration methods that are well suited for the geology of China (Dai et al, 1992; Xu, 1994). These findings have played a central role in natural gas exploration in China. Most traditional geology theories are dependent on the information provided by $\mathrm{C}_{1}, \mathrm{C}_{2}$ and $\mathrm{C}_{3}\left(\mathrm{C}_{1}\right.$ : methane, $\mathrm{C}_{2}$ : ethane, $\mathrm{C}_{3}$ : propane), which cannot be used to recognize the origin of natural gas because they have small molecular

*Corresponding author. email: xueyubinghu@yahoo.com.cn Received July 20, 2011 diameters, and can easily diffuse, dissolve, and be reworked by microorganisms. The molecular diameter of butane $\left(\mathrm{C}_{4}\right)$ is relatively large, and butane does not dissolve easily in water. Moreover, isobutane $\left(i-\mathrm{C}_{4}\right)$ is highly resistant to biological degradation. These characteristics of butane can be useful in solving the problems generally associated with shortchain alkanes. In recent years, scientists have studied the geochemical characteristics of butane, primarily from the following aspects ( $\mathrm{Li}$ et al, 2006; Huang et al, 1997; Gao et al, 2008; Zhang et al, 2003; Hu et al, 1998; Tinivella et al, 2008; Wang et al, 2008): surface geochemical prospecting for oil and gas, gas diffusion coefficients, identification of biodegradation gas, routine analysis of natural gas, the FischerTropsch reaction, the characteristics of the components in a hydrate, the difference between oil-cracked gas and kerogencracked gas. Based on the characteristics of butane in the natural gas from the Tarim, Ordos, Kailu and Donghai basins, we examined the application of butane geochemical 
characteristics in the identification of gas types, maturity and migration direction. The main data and their sources are shown in Table 1.

\section{Butane geochemical characteristics in different types of natural gas}

The classification of gas types plays an important role in the identification of their origins. The primary methods to identify the gas type include carbon isotopic signatures of ethane and propane (Dai et al, 1992), the light hydrocarbon component and its carbon isotope data (C-isotope) (Prinzhofer and Pernaton, 1997; George et al, 2002), and the C-isotope series features of alkanes (Dai et al, 2008). Among these, the $\mathrm{C}$-isotope ratios of ethane is currently the most effective and widely used method to identify gas types. Generally, $\delta^{13} \mathrm{C}_{\text {ethane }}$ values greater than $-25.1 \%$ and less than $-28.8 \%$ can indicate the relative abundance of coal-type gas and oil-type gas (Dai et al, 1992), respectively. To improve the effectiveness of the parameters, we use butane composition and carbon isotopic signatures to identify the gas types.

\subsection{The relationship between the butane composition and types of gas}

High-quality oil-type source rocks have a high proportion of kerogen with aliphatic groups and generate gases with low $i-\mathrm{C}_{4} / n-\mathrm{C}_{4}$ ratios (volume ratio of isobutane/n-butane), whereas coal-type gases that have evolved from low-quality source rocks which have a high proportion of kerogen with branched chain groups have high $i-\mathrm{C}_{4} / n-\mathrm{C}_{4}$ ratios. Thermal simulation experiments also confirmed that the $i-\mathrm{C}_{4} / n-\mathrm{C}_{4}$ ratios increase with worsening of the organic types (Gao et al, 2003). However, a high $i-\mathrm{C}_{4} / n-\mathrm{C}_{4}$ ratio does not necessarily mean low-quality source rocks.

Table 1 Characteristics of the gas components and carbon isotopes in China's major gas-bearing basins

\begin{tabular}{|c|c|c|c|c|c|c|c|c|c|c|c|c|c|c|}
\hline \multirow{2}{*}{ Basin } & \multirow{2}{*}{ Region } & \multirow{2}{*}{ Oil well } & \multirow{2}{*}{$\begin{array}{l}\text { Producing } \\
\text { formation }\end{array}$} & \multicolumn{5}{|c|}{ Gas component characteristics, $\%$} & \multicolumn{5}{|c|}{$\begin{array}{l}\text { Gas carbon isotope characteristics } \\
\text { (PDB), \%o }\end{array}$} & \multirow{2}{*}{ Remark } \\
\hline & & & & $\mathrm{C}_{1}$ & $\mathrm{C}_{2}$ & $\mathrm{C}_{3}$ & $i-\mathrm{C}_{4}$ & $n-\mathrm{C}_{4}$ & $\delta^{13} \mathrm{C}_{1}$ & $\delta^{13} \mathrm{C}_{2}$ & $\delta^{13} \mathrm{C}_{3}$ & $\delta^{13} \mathrm{C}_{i-4}$ & $\delta^{13} \mathrm{C}_{n-4}$ & \\
\hline \multirow{13}{*}{$\begin{array}{l}\text { Kailu } \\
\text { Basin }\end{array}$} & \multirow{13}{*}{$\begin{array}{c}\text { Naiman } \\
\text { Depression }\end{array}$} & Nai 1-48-46 & $\mathrm{K}_{1} j f$ & 28.5 & 7.6 & 15.4 & 4.3 & 10.0 & -51.4 & -40.5 & -35.0 & -34.8 & -32.0 & \multirow{13}{*}{$\begin{array}{c}\text { The samples were } \\
\text { analyzed at the } \\
\text { National } \\
\text { Research Center } \\
\text { for Geoanalysis, } \\
\text { Chinese Academy } \\
\text { of Geological } \\
\text { Sciences }\end{array}$} \\
\hline & & Nai 1-58-56 & $\mathrm{K}_{1} j f$ & 18.1 & 3.2 & 7.1 & 2.5 & 5.0 & -53.3 & -40.0 & -34.9 & -33.8 & -32.0 & \\
\hline & & Nai $1-48-50$ & $\mathrm{~K}_{1} j f$ & 33.9 & 7.6 & 13.4 & 3.2 & 6.4 & -53.2 & -40.6 & -35.3 & -34.6 & -32.1 & \\
\hline & & Nai 1-54-44 & $\mathrm{K}_{1} j f$ & 34.1 & 5.3 & 11.5 & 3.3 & 6.4 & -53.4 & -40.4 & -34.9 & -33.8 & -32.0 & \\
\hline & & Nai 1-60-46 & $\mathrm{K}_{1} j f$ & 32.9 & 5.9 & 11.0 & 2.8 & 5.6 & -54.3 & -40.8 & -35.1 & -33.9 & -32.1 & \\
\hline & & Nai $1-42-40$ & $\mathrm{~K}_{1} j f$ & 35.6 & 7.0 & 12.1 & 2.4 & 5.4 & -56.1 & -42.1 & -35.7 & -35.0 & -32.3 & \\
\hline & & Nai 1-62-52 & $\mathrm{K}_{1} j f$ & 17.7 & 2.7 & 5.0 & 1.3 & 3.6 & -52.4 & -40.3 & -35.3 & -34.4 & -32.6 & \\
\hline & & Nai 1-58-44 & $\mathrm{K}_{1} j f$ & 35.3 & 3.8 & 9.5 & 3.3 & 5.9 & -54.4 & -40.1 & -34.7 & -33.6 & -31.9 & \\
\hline & & Nai 1-44-46 & $\mathrm{K}_{1} j f$ & 19.5 & 3.5 & 5.6 & 1.0 & 2.2 & -53.1 & -40.3 & -34.6 & -34.4 & -31.9 & \\
\hline & & Nai $1-42-44$ & $\mathrm{~K}_{1} j f$ & 25.8 & 1.8 & 5.9 & 1.8 & 3.2 & -54.6 & -40.1 & -34.7 & -33.7 & -31.5 & \\
\hline & & Nai 1-76-36 & $\mathrm{K}_{1} j f$ & 29.2 & 1.9 & 6.7 & 2.4 & 3.1 & -54.4 & -40.8 & -35.0 & -33.8 & -32.0 & \\
\hline & & Nai 1-54-52 & $\mathrm{K}_{1}$ if & 44.5 & 2.2 & 6.0 & 2.8 & 4.3 & -57.7 & -42.4 & -34.9 & -33.5 & -31.7 & \\
\hline & & Nai 1-73-32 & $\mathrm{K}_{1} j f$ & 34.2 & 1.2 & 3.9 & 1.4 & 2.2 & -57.8 & -41.3 & -34.3 & -33.9 & -31.4 & \\
\hline \multirow{7}{*}{$\begin{array}{l}\text { Tarim } \\
\text { Basin }\end{array}$} & \multirow{7}{*}{$\begin{array}{l}\text { Tazhong } \\
\text { Uplift }\end{array}$} & $\begin{array}{c}\text { Tazhong } \\
62-1\end{array}$ & $\mathrm{O}$ & 90.2 & 1.6 & 0.7 & 0.2 & 0.4 & -38.0 & -33.6 & -30.2 & -28.1 & -29.3 & \multirow{7}{*}{$\begin{array}{c}\text { The samples were } \\
\text { analyzed at the } \\
\text { Langfang } \\
\text { Branch of the } \\
\text { Research } \\
\text { Institute of Petroleum } \\
\text { Exploration and } \\
\text { Development of } \\
\text { CNPC }\end{array}$} \\
\hline & & $\begin{array}{c}\text { Ta } \mathrm{zh} \text { o n g } \\
622\end{array}$ & $\mathrm{O}$ & 92.2 & 1.2 & 0.4 & 0.1 & 0.2 & -38.9 & -33.8 & -31.1 & -28.7 & -30.3 & \\
\hline & & $\begin{array}{c}\text { Tazhong } \\
62-2\end{array}$ & $\mathrm{O}$ & 91.0 & 1.3 & 0.4 & 0.1 & 0.2 & -38.9 & -31.7 & -30.3 & -28.6 & -28.7 & \\
\hline & & $\begin{array}{c}\text { Tazhong } \\
62-3\end{array}$ & $\mathrm{O}$ & 86.7 & 1.7 & 0.7 & 0.2 & 0.4 & -38.7 & -33.5 & -30.1 & -28.5 & -29.9 & \\
\hline & & Tazhong 82 & $\mathrm{O}$ & 84.6 & 3.2 & 1.3 & 0.3 & 0.5 & -39.6 & -33.8 & -30.6 & -28.9 & -29.0 & \\
\hline & & $\begin{array}{c}\text { Tazh o n g } \\
821\end{array}$ & $\mathrm{O}$ & 87.6 & 1.4 & 0.6 & 0.2 & 0.3 & -38.3 & -33.1 & -30.2 & -28.3 & -29.4 & \\
\hline & & $\begin{array}{c}\text { Tazhong } \\
4-7-38\end{array}$ & $\mathrm{O}$ & 78.7 & 3.2 & 1.8 & 0.2 & 0.5 & -37.6 & -44.6 & -38.1 & -33.4 & -34.5 & \\
\hline
\end{tabular}


(Continued)

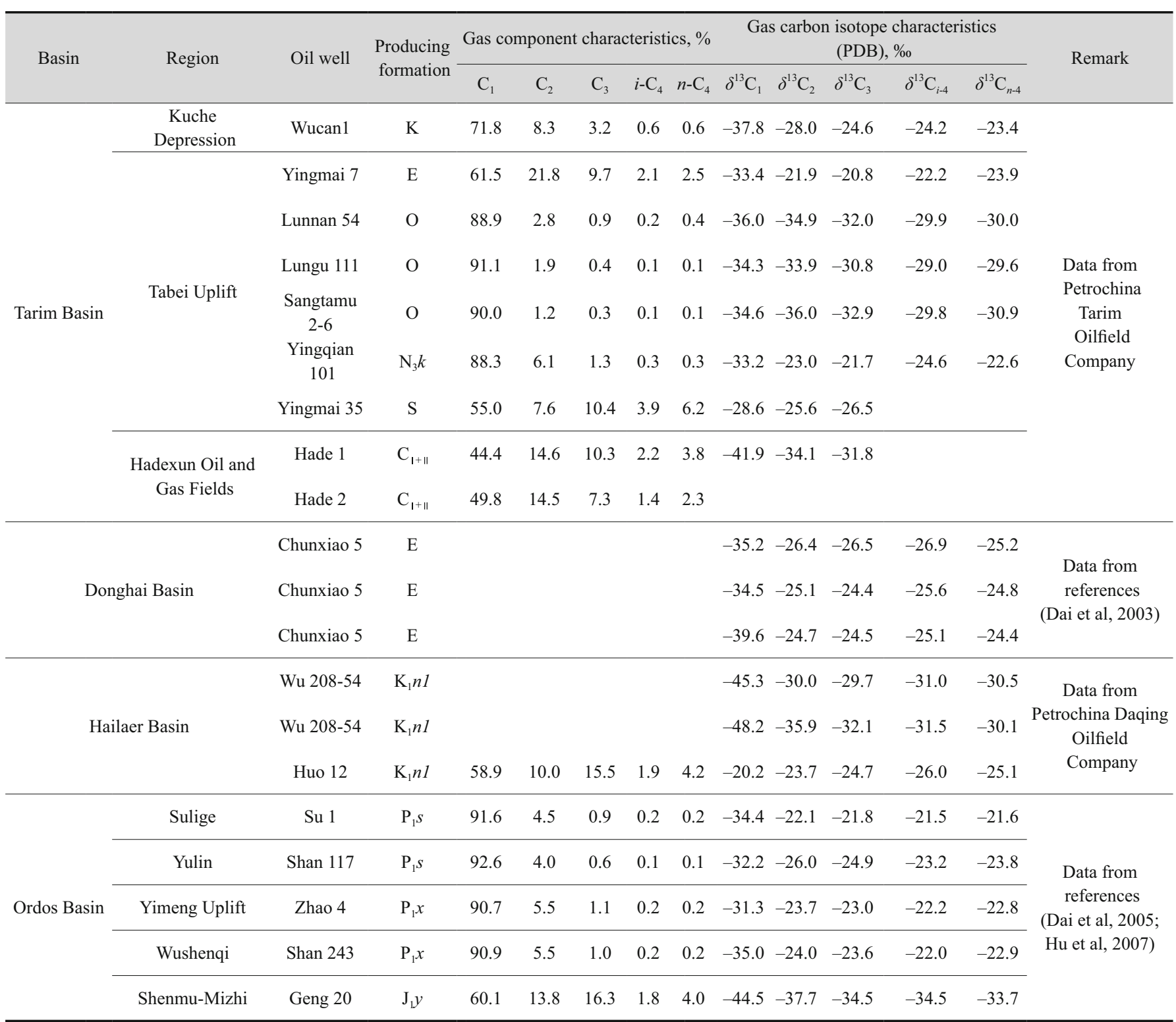

$\mathrm{High} i-\mathrm{C}_{4} / n-\mathrm{C}_{4}$ ratios may also be caused by biodegradation, that is, hydrocarbon-oxidizing bacteria first consume $n-\mathrm{C}_{4}$, leaving out $i-\mathrm{C}_{4}$ which resists biodegradation. For example, in the Carnarvon Basin of Australia, almost all oil-type gases derived from the Triassic-Jurassic formation have suffered biodegradation and $i-\mathrm{C}_{4} / n-\mathrm{C}_{4}$ is greater than 1 , whereas oil-type gases that have not suffered biodegradation have $i-\mathrm{C}_{4} / n-\mathrm{C}_{4}$ ratios lower than 0.85 , ranging from 0.43 to 0.85 , with an average value of 0.63 (Boreham and Edwards, 2008).

Statistical analysis of the relationship between the $i-\mathrm{C}_{4} /$ $n-\mathrm{C}_{4}$ ratio and the gas types based on 214 gas samples from the Tarim (Miao et al, 2011), Ordos, Kailu and East China Sea basins shows that $\delta^{13} \mathrm{C}_{2}>-25.1 \%$ and $80 \%$ of $i-\mathrm{C}_{4} / n-\mathrm{C}_{4}$ values $>0.8$ indicate a typical coal-gas, whereas $\delta^{13} \mathrm{C}_{2}<$ $-28.8 \%$ and $85 \%$ of $i-\mathrm{C}_{4} / n-\mathrm{C}_{4}$ values $<0.8$ indicate a typical oil-gas (Fig. 1). Whether or not the value of $i-\mathrm{C}_{4} / n-\mathrm{C}_{4}$ exceeds 0.8 can therefore be utilized to distinguish the type of gas.

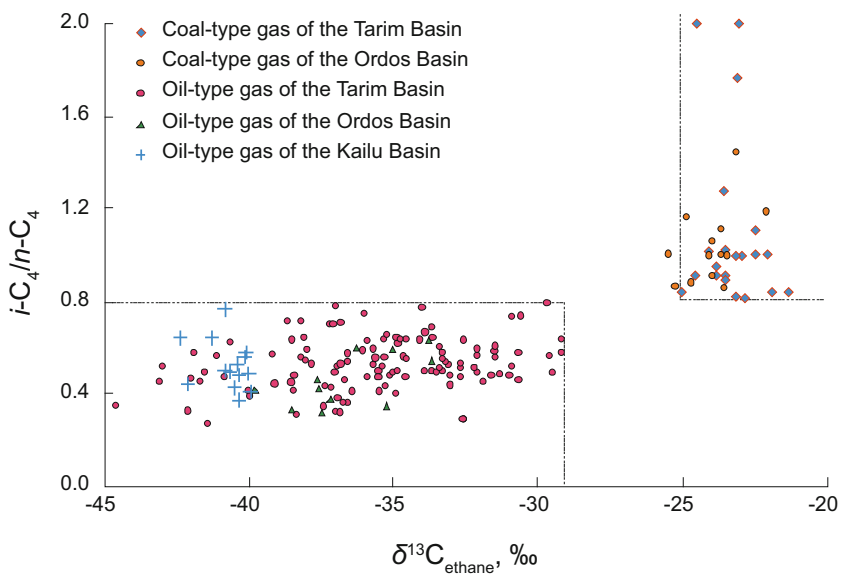

Fig. 1 The relationship between the characteristics of the butane components and the types of gas 


\subsection{The relationship between the characteristics of the $\mathbf{C}$-isotope of butane and gas types}

The carbon isotope of ethane is the most common and effective parameter to classify the gas type because it inherits the carbon isotopic signature from the source material and is not influenced by the maturity of the source material. The carbon isotopes of butane, $n$-butane and isobutane show a high positive correlation with the carbon isotope of ethane. Therefore, the carbon isotopes inherit the isotopic signature of the source material, which can then reflect the genetic type of the natural gas. As shown in Fig. 2, the $\delta^{13} \mathrm{C}_{\text {butane }}$ of a coaltype gas is generally greater than $-25.5 \%$ and that of an oiltype gas is less than $-28 \%$ (Fig. 2(a)). The $\delta^{13} \mathrm{C}_{\text {isobutane }}$ value is often greater than $-24 \%$ for a coal-type gas, whereas this value is generally less than $-27 \%$ for an oil-type gas (Fig. 2(b)). The $\delta^{13} \mathrm{C}_{n \text {-butane }}$ value is often greater than $-26 \%$ for a coal-type gas, whereas it is generally less than $-28.5 \%$ for an oil-type gas (Fig. 2(c)).

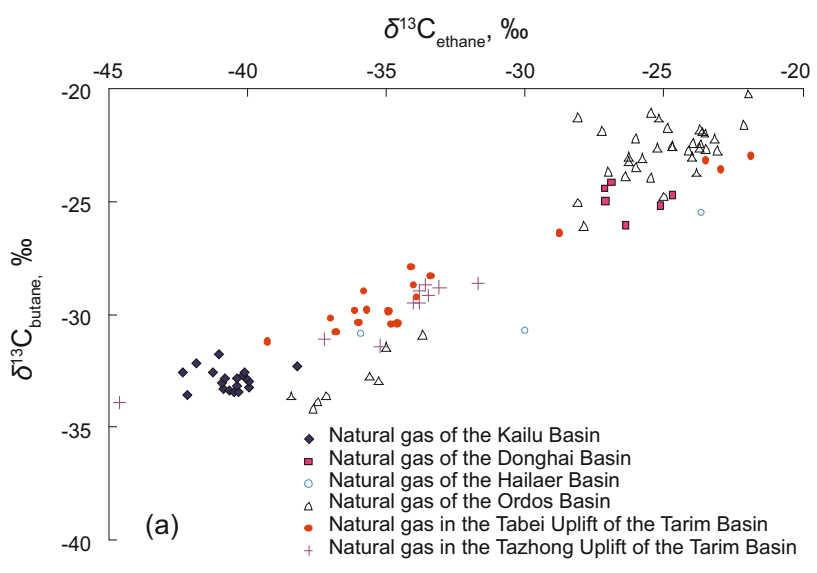

(a) The characteristics of $\mathrm{C}_{4}$-isotopes in different natural gas types

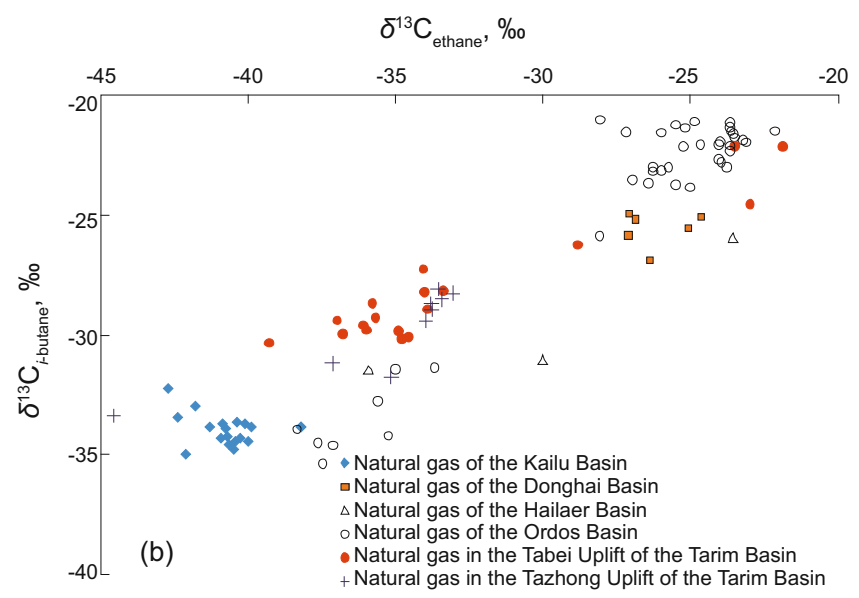

(b) The relationship between the characteristics of $\mathrm{C}_{i \text {-butane }}$-isotopes and natural gas types

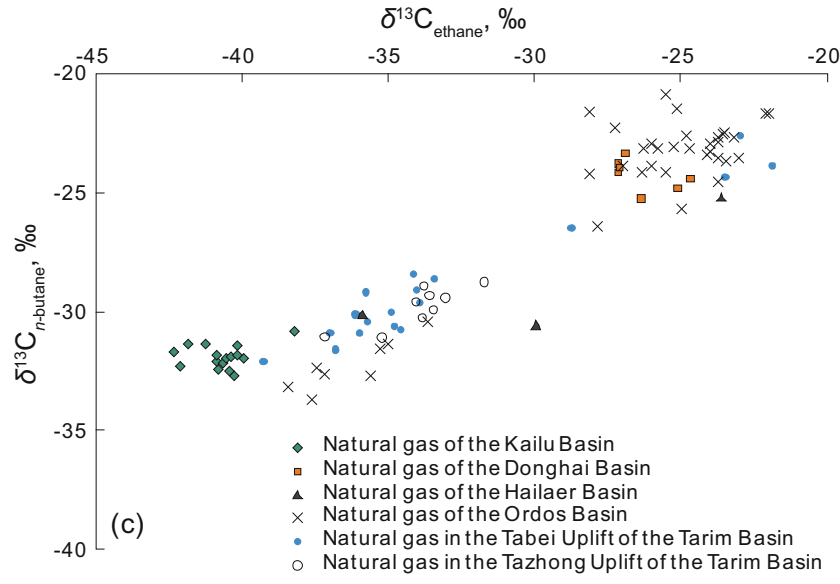

(c) The relationship between the characteristics of $\mathrm{C}_{n \text {-butane }}$-isotopes and natural gas types

Fig. 2 The relationship between the characteristics of $\mathrm{C}_{4}$-isotopes and natural gas types

\section{The impact of maturity on the geochemical characteristics of butane}

\subsection{Variation of the butane content with the degree of maturity}

Source rocks can produce gaseous hydrocarbons with markedly different compositional characteristics at various evolutionary stages. The dry coefficient $\left(\mathrm{C}_{1} / \mathrm{C}_{1-5}\right.$, volume ratio) is very high (greater than $95 \%$ ) and the butane content is very low at the biological gas stage. At the bio-catalytic transition stage, the alkane content increases, but remains highly variable. The hydrocarbon gases, composed mainly of $\mathrm{C}_{1}$ and a certain amount of heavier hydrocarbon gases (primarily $\mathrm{C}_{2}$ and $\mathrm{C}_{3}$ ), have a high dry coefficient (Xu et al, 1990; Liu et al, 1997). For such gases, no information on the characteristics of the butane content has previously been reported. When the source rocks have evolved to the oil window stage $\left(R_{\mathrm{o}}>0.6 \%\right)$, the content of butane gradually increases along with a concomitant increase in maturity. When the source rocks have evolved up to the early period of the high-maturity stage $\left(R_{\mathrm{o}}= \pm 1.3 \%\right)$, the volume fraction of the butane reaches its peak. After this $\left(R_{\mathrm{o}}>1.3 \%\right)$, the butane content decreases with an increase of source rock maturity.

With the increase in maturity, heavy carbon isotopes accumulate in the hydrocarbon gas and the difference values of $\mathrm{C}_{1}, \mathrm{C}_{2}$, and $\mathrm{C}_{3}$ become small $\left(\delta^{13} \mathrm{C}_{2}-\delta^{13} \mathrm{C}_{1}, \delta^{13} \mathrm{C}_{3}-\delta^{13} \mathrm{C}_{1}\right.$, $\left.\delta^{13} \mathrm{C}_{3}-\delta^{13} \mathrm{C}_{2}\right)$. When the source rocks have evolved to the highover-maturity stage, the value of $\delta^{13} \mathrm{C}_{\text {ethane }}-\delta^{13} \mathrm{C}_{\text {methane }}$ gradually decreases due to the reversal of the relative carbon isotopic contribution from methane and ethane (Fuex, 1977; James, 1983). The value of $i-\mathrm{C}_{4} / n-\mathrm{C}_{4}$ does not change with increasing maturity (Fig. 3) for either the coal-type or the oil-type gas, which shows that the compositional characteristics of butane are not influenced by the source rock maturity. 


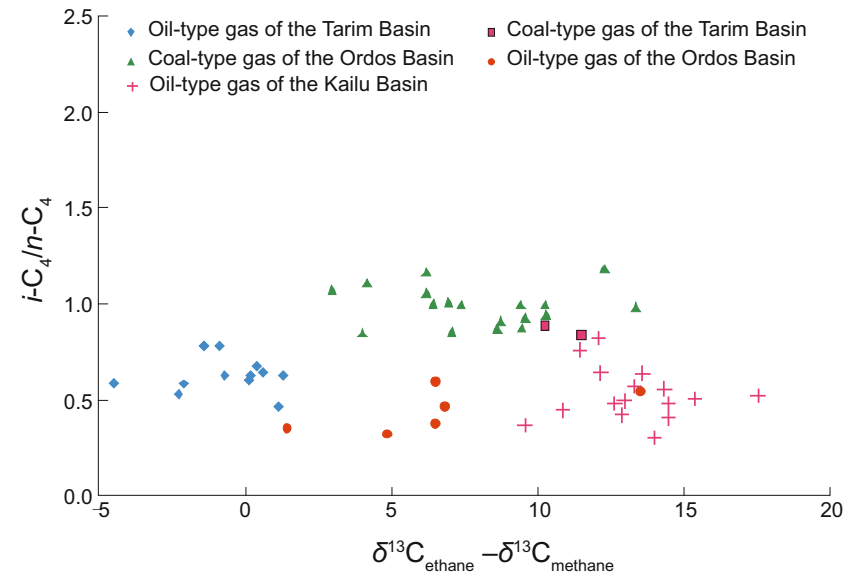

Fig. 3 The relationship between $i-\mathrm{C}_{4} / n-\mathrm{C}_{4}$ and the maturity of the natural gas

\subsection{The relationship between the $\mathrm{C}$-isotope ratios of butane and the maturity}

Isotopic fractionation occurs during the thermal evolution of a kerogen, for example, carbon isotopes of $n-\mathrm{C}_{4}$ and $i-\mathrm{C}_{4}$ become heavier with increasing maturity. However, with an increase in maturity, the heavier $\mathrm{C}$-isotope of $i-\mathrm{C}_{4}$ increases at a faster rate than that of $n$-C C $_{4}$ (Fig. 4(a), Fig. 4(b)).

One reason behind the different rate of $\mathrm{C}$-isotope evolution with increasing maturity could be the sources of $n-\mathrm{C}_{4}$ and $i-\mathrm{C}_{4}$. At a low evolutionary stage, $i-\mathrm{C}_{4}$ is primarily produced from the side chain of a macromolecule of a kerogen, whereas in addition to the side chain of a macromolecule, $n$ - $\mathrm{C}_{4}$ is produced from the cracking of a long-chain alkane, so the C-isotope ratio obtained from $n-\mathrm{C}_{4}$ becomes heavier than that obtained from $i-\mathrm{C}_{4}$. With an increase in maturity, the $i-\mathrm{C}_{4}$ derived from the macromolecules in kerogen is completely differentiated. Moreover, $i-\mathrm{C}_{4}$ can also be generated from the isomerization of a long-chain alkane during the process of thermal cracking. Though $n-\mathrm{C}_{4}$ can also be generated from thermal cracking of a long-chain alkane, isomerization does not occur in its evolutionary process. Therefore, the carbon isotope of $n-\mathrm{C}_{4}$ becomes progressively lighter than that of $i-\mathrm{C}_{4}$ because of the limited scope of generation.

At a low evolutionary stage, the heavy carbon isotope in $n-\mathrm{C}_{4}$ is relatively abundant, and the $\delta^{13} \mathrm{C}_{\text {isobutane }}-\delta^{13} \mathrm{C}_{n \text {-butane }}$ value is less than 0 . With an increase in maturity, $\delta^{13} \mathrm{C}_{\text {isobutane }}-$ $\delta^{13} \mathrm{C}_{n \text {-butane }}$ increases because of the convergence of the carbon isotope values of $n-\mathrm{C}_{4}$ and $i-\mathrm{C}_{4}$. At the high-over-maturity stage, the heavy carbon isotope in $i-\mathrm{C}_{4}$ is relatively abundant, and $\delta^{13} \mathrm{C}_{\text {isobutane }}-\delta^{13} \mathrm{C}_{n \text {-butane }}$ is greater than 0 (Fig. 4(c), Fig. $4(d))$.

The value of $\delta^{13} \mathrm{C}_{\text {isobutane }}-\delta^{13} \mathrm{C}_{n \text {-butane }}$ is influenced by the degree of thermal evolution. Therefore, it could be used to estimate the maturity of the natural gas. For example, the maturity of the coal-type gas from the Cenozoic in the Xihu Depression is lower than that of a similar type gas from the Paleozoic in the Ordos Basin. $\delta^{13} \mathrm{C}_{\text {isobutane }}-\delta^{13} \mathrm{C}_{n \text {-butane }}$ in the Xihu Depression ranges from $-0.7 \%$ to $-1.9 \%$, whereas in the Ordos Basin, it ranges from $-0.4 \%$ to $2.6 \%$, with an average value of $0.8 \%$. Although the types of gases in the Paleozoic are different in the Tarim and Ordos basins, both the basins exhibit high maturity, and the $\delta^{13} \mathrm{C}_{\text {isobutane }}-\delta^{13} \mathrm{C}_{n \text {-butane }}$ values are generally greater than 0 .

In China's major gas-bearing basins, the source rock of oil-type gas is from Paleozoic with a $R_{\mathrm{o}}$ value that ranges from $1.4 \%$ to $3.3 \%$, with an average of $2.4 \%$, whereas for source rock of coal-type gas, the $R_{\mathrm{o}}$ value ranges from $0.7 \%$ to $2.8 \%$, with an average value of $1.4 \%$. The value of $\delta^{13} \mathrm{C}_{\text {isobutane }}$ $-\delta^{13} \mathrm{C}_{n \text {-butane }}$ is almost always greater than 0 . Additionally, the oil-type gas is derived from Mesozoic and Cenozoic source rock with a $R_{\mathrm{o}}$ between $0.7 \%$ and $2.2 \%$, with an average value of $1.1 \%$, whereas for the coal-type gas, the source rock $R_{\mathrm{o}}$ ranges from $0.4 \%$ to $1.0 \%$, with an average value of $0.8 \%$. The value of $\delta^{13} \mathrm{C}_{\text {isobutane }}-\delta^{13} \mathrm{C}_{n \text {-butane }}$ is almost always less than 0 . Therefore, it can be concluded that $R_{\mathrm{o}}$ is greater than $2.4 \%$ and $1.4 \%$ for the oil-type and coal-type gas, respectively, when $\delta^{13} \mathrm{C}_{\text {isobutane }}-\delta^{13} \mathrm{C}_{n \text {-butane }}$ is greater than 0 . In contrast, when $\delta^{13} \mathrm{C}_{\text {isobutane }}-\delta^{13} \mathrm{C}_{n \text {-butane }}$ is less than $0, R_{\mathrm{o}}$ is less than $1.1 \%$ and $0.8 \%$ for the oil-type and coal-type gas, respectively.

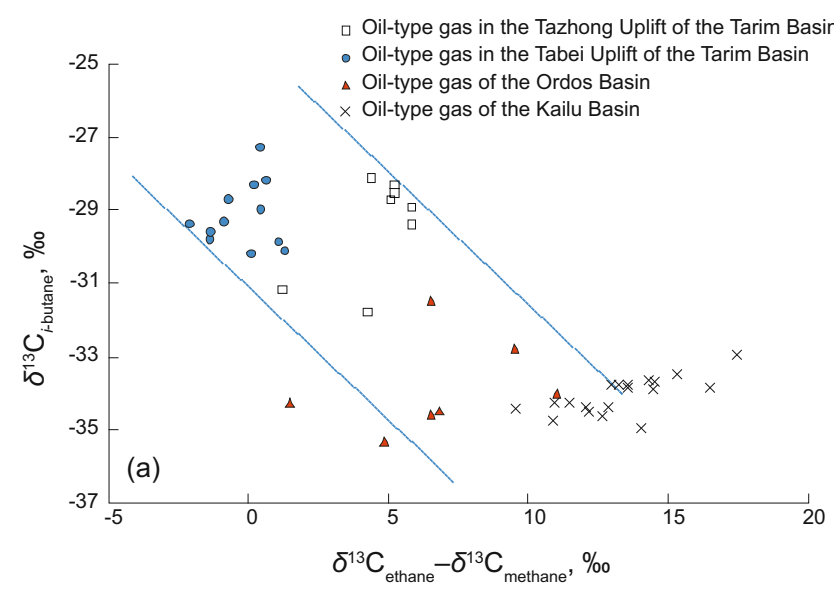

(a) $i-\mathrm{C}_{4}$ evolutionary characteristics of an oil-type gas with maturity

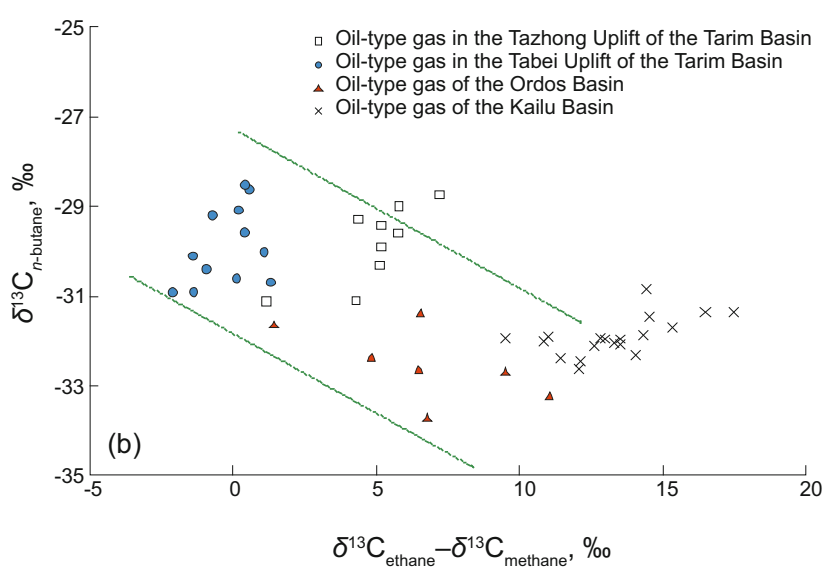

(b) $n-\mathrm{C}_{4}$ evolutionary characteristics of an oil-type gas with maturity 


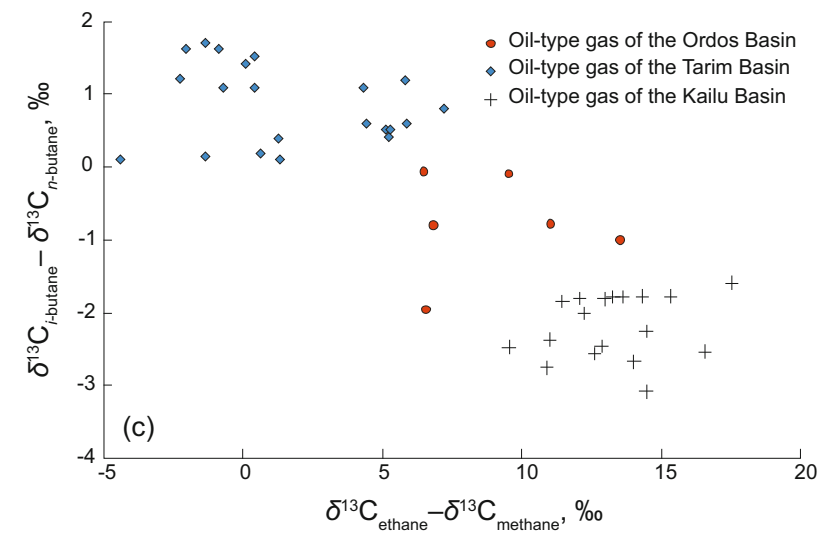

(c) The relationship between $\delta^{13} \mathrm{C}_{i \text {-butane }}-\delta^{13} \mathrm{C}_{n \text {-butane }}$ and maturity in an oil-type gas

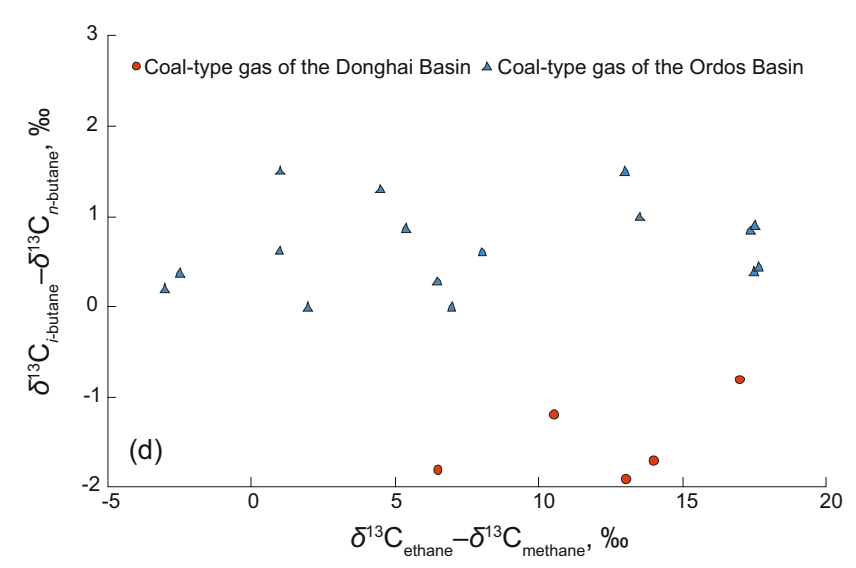

(d) The relationship between $\delta^{13} \mathrm{C}_{i \text {-butane }}-\delta^{13} \mathrm{C}_{n \text {-butane }}$ and maturity in a coal-type gas

Fig. 4 The relationship between the characteristics of $\mathrm{C}_{4}$ and the maturity of natural gas

\section{The geochemical characteristics of butane from a bio-thermocatalytic transition zone gas}

\subsection{Bio-thermocatalytic transition zone gas in the Kailu Basin}

Bio-thermocatalytic transition zone gas, known simply as transition zone gas (Liu et al, 1997), is generated under the action of exogenous factors when the biological effect on the organic matter is close to completion but has not yet reached the oil window stage. The main indicators for transition zone gas are as follows (Liu et al, 1997): (1) source rocks primarily developed in the Mesozoic and Cenozoic with a burial depth of less than $3,000 \mathrm{~m}$; (2) $\delta^{13} \mathrm{C}_{\text {methane }}$ ranges from $-60 \%$ to $-45 \%$; (3) dry coefficients range from 0.4 to 1.0 , with methane coexisting with a certain amount of heavier hydrocarbons; (4) positive carbon isotopic sequence of the hydrocarbon gases. In addition, gases with $\delta^{13} \mathrm{C}_{2}$ less than $-30 \%$ are classified as sapropelic transition zone gases, whereas a $\delta^{13} \mathrm{C}_{2}$ range of $-38 \%$ to $-26 \%$ indicates a sapropelic-humic transition zone gas.

The Naiman Depression of the Kailu Basin, which overlies a pre-Mesozoic basement, is a Mesozoic and Cenozoic oilbearing sequence that comprises the following units from the top: pre-Mesozoic basement, Hadataolegai Formation of the lower Triassic, Haifanggou Formation of the middle Jurassic, Jiufotang Formation $\left(\mathrm{K}_{1} j f\right)$, Shahai Formation $\left(\mathrm{K}_{1} s h\right)$, Fuxin Formation $\left(\mathrm{K}_{1} f\right)$ of the lower Cretaceous, the upper Cretaceous $\left(\mathrm{K}_{2}\right)$, Cenozoic. The Jiufotang Formation, which is buried at a depth of 1,353-2,678 $\mathrm{m}$, is a major reservoir in this area. The primary source rock of the Jiufotang and Shahai formations is a dark lacustrine mudstone.

The natural gas samples from the Jiufotang Formation in the Naiman Depression were analyzed. The $\delta^{13} \mathrm{C}_{\text {methane }}$ values range from $-57.8 \%$ to $-49.5 \%$, while the dry coefficients range from 0.4 to 0.8 . The carbon isotopic values of the hydrocarbon gases are positive sequence, and $\delta^{13} \mathrm{C}_{\text {ethane }}$ is less than $-39.9 \%$. Evidently, the natural gas in this area can be classified as a typical sapropelic transition zone gas.

\subsection{The geochemical characteristics of butane in bio-thermocatalytic transition zone gas in the Kailu Basin}

The butane content in the sapropelic transition zone gas of the Naiman Depression varies from $2.4 \%$ to $14.3 \%$, and the majority of the $i-\mathrm{C}_{4} / n-\mathrm{C}_{4}$ values are below 0.8 because of the influence of the source material. The carbon isotope ratios of $n$-butane and isobutane show little fluctuation and vary from $-32.6 \%$ to $-31.4 \%$ and from $-35.0 \%$ to $-33.5 \%$, respectively, without any detectable influence of methane or ethane carbon isotopes. Compared to $i-\mathrm{C}_{4}, n-\mathrm{C}_{4}$ is preferentially enriched with the heavy carbon isotope, and all the values of $\delta^{13} \mathrm{C}_{\text {isobutane }}-\delta^{13} \mathrm{C}_{n \text {-butane }}$ are less than $-1.5 \%$, with a minimum of $-2.8 \%$ (Figs. 1-4), which is significantly less than that observed in the thermogenic gas. $n$ - $\mathrm{C}_{4}$ has a poor resistance to biodegradation, and the lighter $\mathrm{C}$-isotope of $n-\mathrm{C}_{4}$ is more easily consumed by microorganisms. Therefore, heavy $\mathrm{C}$-isotope is enriched in $n$ - $\mathrm{C}_{4}$ of natural gas that has undergone biodegradation, and the value of $\delta^{13} \mathrm{C}_{\text {isobutane }}{ }^{-}$ $\delta^{13} \mathrm{C}_{n \text {-butane }}$ is the lowest among all the types of gases. For example, the $\delta^{13} \mathrm{C}_{\text {isobutan }}-\delta^{13} \mathrm{C}_{n \text {-butane }}$ of the oil-type gas from the Triassic-Jurassic in the Carnarvon Basin in Australia that has undergone biodegradation varies from $-9.1 \%$ to $-0.4 \%$, with an average value of $-4.9 \%$ (Boreham and Edwards, 2008), which is significantly less than that observed in the bio-thermocatalytic transition zone gas from the Naiman Depression. The geochemical characteristics of butane from the Bohai Bay Basin are similar to the above Carnarvon Basin (Yang et al, 2012).

Overall, compared with the other types of gases that have a biogenic or thermogenic origin, sapropelic transition zone gas clearly accumulates butane. The $i-\mathrm{C}_{4} / n-\mathrm{C}_{4}$ ratio exhibits no obvious difference when compared with the value observed in a thermogenic gas, and therefore, different organic types of gases can be effectively distinguished. The carbon isotopic characteristics of butane found in the transition zone gas are similar to those of any thermogenic gas at a low stage of maturity. However, the range of variation is smaller and 
more stable. The capacity for enrichment of the heavy carbon isotope in n-butane relative to isobutane (i.e. $\delta^{13} \mathrm{C}_{\text {isobutane }}$ $-\delta^{13} \mathrm{C}_{n \text {-butane }}$ ) is greater than that observed in thermogenic gases and less than that observed in a biodegradable transition zone gas.

\section{Variation of geochemical characteristics of butane during gas migration}

Differentiation of the butane components in the process of migration is controlled by the relationship between the molecular diameter of butane and the pore throat in the formation, migration morphology, and the molecular shape. Differentiation of butane components does not occur in gases that are dissolved in water and oil because the diameter and polarity of the carrier molecules are much larger than those of the butane molecules. Furthermore, the large conducting channels are not conducive for the differentiation of the butane components. For example, in the Lunnan Uplift of the Sangtamu Fault Belt of the Tarim Basin, natural gases from the Ordovician and Carboniferous reservoirs that are connected by faults have very similar values of $i-\mathrm{C}_{4} / n-\mathrm{C}_{4}$, with an average value of approximately 0.55 (Miao et al, 2011).

The $i-\mathrm{C}_{4} / n-\mathrm{C}_{4}$ value of natural gas which migrates as a free phase, is determined by the molecular shape, and the relationship between the molecular diameters of butane and those of the pore throats. The molecular shape of $i-\mathrm{C}_{4}$ is nearly spherical, with a molecular dynamics diameter of 0.50 $\mathrm{nm}$, whereas the molecular shape of $n-\mathrm{C}_{4}$ is nearly linear, with a molecular dynamics diameter of $0.43 \mathrm{~nm}$. Usually $n-\mathrm{C}_{4}$ migrates faster because its molecular diameter is narrower than that of $i-\mathrm{C}_{4}$, which can effectively reduce the value of $i-\mathrm{C}_{4} / n-\mathrm{C}_{4}$. However, when the pore throat is very small, the influence of the molecular diameter on the migration velocity is not significant. In such a situation, the molecular shape imposes restrictions on the migration rate. More specifically, the nearly spherical $i-\mathrm{C}_{4}$ molecule has relatively fast migration rates, which increases the $i-\mathrm{C}_{4} / n-\mathrm{C}_{4}$ ratio along the migration direction. The faster migration rates are because of the skeleton vibration and telescopic bending vibration of the guest molecules, which reduce the resistance of migration in the spherical molecules. The aforementioned hypothesis has been confirmed by physical simulation and molecular sieve experiments (Shi et al, 2005; Zhang et al, 2007).

In geological reservoirs, natural gas can seep through the cap rocks in a process similar to migration in a layer with very small pore throats (Miao et al, 2011). For example, in the Yingnan 2 Well in the southeast of the Tarim Basin, the gas from the Silurian (Huang et al, 2006) is at a depth of $3,805.5$ to $3,834.0 \mathrm{~m}$, with an $i-\mathrm{C}_{4} / n-\mathrm{C}_{4}$ value of 0.51 . The value of $i-\mathrm{C}_{4} / n-\mathrm{C}_{4}$ increases up to 0.74 (Zhang et al, 2004) in the Jurassic, which is at a depth of 3,471 to $3,502 \mathrm{~m}$. The process by which the natural gas migrated from the structural low to the high is similar to gas migration along large pore throats in a carrier bed. For example, in Xiang-II Formation of Bajiaochang Oil and Gas Field of the Sichuan Basin, gas migrates from the tectonic northern flank to the top of the traps with a concomitant reduction in the $i-\mathrm{C}_{4} / n-\mathrm{C}_{4}$ value from
1.16 to 0.80 (Wang and Yang, 1986).

\section{Conclusions}

1) The $i-\mathrm{C}_{4} / n-\mathrm{C}_{4}$ values and carbon isotopic signatures of butane can be used to effectively distinguish different natural gas types. Typical values for oil-type gases are $i-\mathrm{C}_{4} / n-\mathrm{C}_{4}<0.8$, $\delta^{13} \mathrm{C}_{\text {butane }}<-28 \%$ o,$\delta^{13} \mathrm{C}_{\text {isobutane }}<-27 \%$ o, $\delta^{13} \mathrm{C}_{n \text {-butane }}<-28.5 \%$, whereas the corresponding values for the coal-type gases are $i-\mathrm{C}_{4} / n-\mathrm{C}_{4}>0.8, \delta^{13} \mathrm{C}_{\text {butane }}>-25.5 \%$ o, $\delta^{13} \mathrm{C}_{\text {isobutane }}>-24 \%$, $\delta^{13} \mathrm{C}_{n \text {-butane }}>-26 \%$.

2) More heavy $\mathrm{C}$-isotopes are enriched in $n$-butane than in isobutane, at the low maturity stage $\left(\delta^{13} \mathrm{C}_{\text {isobutane }}-\delta^{13} \mathrm{C}_{n \text {-butane }}<0\right)$. The carbon isotope ratio of butane gradually becomes heavier with an increase in maturity. Meanwhile, the rate of increase in the heavy carbon isotope content in isobutane is faster than that in $n$-butane, and therefore $\delta^{13} \mathrm{C}_{\text {isobutane }}-\delta^{13} \mathrm{C}_{n \text {-butane }}$ is greater than 0 at the high-over-maturity stage.

3) The content of butane is relatively high in sapropelic bio-thermocatalytic transition zone gas, and the $i-\mathrm{C}_{4} / n-\mathrm{C}_{4}$ is less than 0.8. Additionally, the carbon isotopic characteristics of butane vary only by a small amount. The enrichment of the heavy carbon isotope in $n$-butane relative to the isobutane is stronger for a thermogenic gas than that for a biogenic gas. The natural gas from biodegradation is enriched in isobutane, whereas the carbon isotope of the $n$-butane becomes significantly heavy. All of the above indicate an exceptionally high $i-\mathrm{C}_{4} / n-\mathrm{C}_{4}$ as well as an exceptionally low $\delta^{13} \mathrm{C}_{\text {isobutane }}$ $\delta^{13} \mathrm{C}_{n \text {-butane. }}$.

4) In the process of gas migration, the value of $i-\mathrm{C}_{4} / n-\mathrm{C}_{4}$ is influenced by molecular dynamics diameter, molecular shape, the characteristics of the pore throat geometry, and migration patterns. Under geological conditions, $i-\mathrm{C}_{4} / n-\mathrm{C}_{4}$ increases when a free-phase natural gas passes through a dense cap rock, $i-\mathrm{C}_{4} / n-\mathrm{C}_{4}$ decreases when the gas migrates through a petroleum migration layer.

\section{Acknowledgements}

This work was supported by NSFC (Grant No. 41202100) and the National Science and Technology Major Projects (Grant No. 2008ZX05007-003).

\section{References}

Boreham C J and Edwards D S. Abundance and carbon isotopic composition of neo-pentane in Australian natural gases. Organic Geochemistry. 2008. 39(5): 550-566

Dai J X, Chen J F, Zhong N N, et al. Large Gas Fields in China and Their Gas Sources. Beijing: Science Press. 2003. 157-163 (in Chinese)

Dai J X, Li J, Luo X, et al. Alkane carbon isotopic composition and gas source in giant gas fields of Ordos Basin. Acta Petrolei Sinica. 2005. 26(1): 18-26 (in Chinese)

Dai J X, Ni Y Y, Li J, et al. Carbon isotope types and significances of alkane gases from Junggar Basin and Tarim Basin. Xinjiang Petroleum Geology. 2008. 29(4): 403-410 (in Chinese)

Dai J X, Pei X G and Qi H F. Natural Gas Geology in China (Vol 1). Beijing: Petroleum Industry Press. 1992 (in Chinese)

Fuex A N. The use of stable carbon isotopes in hydrocarbon exploration. Journal of Geochemical Exploration. 1977. 7: 155-188

Gao G, Huang Z L, Liang H, et al. Analysis on selectivity biodegradation of natural gas in Yanmuxi Oilfield of Tuha Basin. Acta Petrolei 
Sinica. 2008. 29(4): 494-498 (in Chinese)

Gao G, Wang Y B, Han D X, et al. Comparison of the characteristics of thermally simulative gas from two types of coal. GeologyGeochemistry. 2003. 31(1): 92-96 (in Chinese)

George S C, Boreham C J, Minifie S A, et al. The effect of minor to moderate biodegradation on $\mathrm{C}_{5}$ to $\mathrm{C}_{9}$ hydrocarbons in crude oils. Organic Geochemistry. 2002. 33(12): 1293-1317

Hu A P, Li J, Zhang W Z, et al. Geochemical characteristics and genetic type comparison of natural gas in the upper and lower Paleozoic and Cenozoic, Ordos Basin. Science in China (Series D). 2007. 37(Supp II): 157-166 (in Chinese)

Hu G X, Ouyang Z Y, Wang X B, et al. Carbon isotopic fractionation in the process of Fischer-Tropsch reaction in primitive solar nebula. Science in China (Series D). 1998. 41(2): 202-207

Huang Z L, Liu G D and Hao S S. Geochemical characteristics of the natural gas migration in the Dongfang1-1 Gasfield, South China Sea. Acta Sedimentologica Sinica. 1997. 15(2): 66-69 (in Chinese)

Huang Z L, Zhang Z Y, Chen J F, et al. Dissipation characteristics of gas in Yingnan-2 gas reservoir in the eastern Tarim Basin. Natural Gas Industry. 2006. 26(9): 12-13 (in Chinese)

James A T. Correlation of natural gas by use of carbon isotopic distribution between hydrocarbon components. AAPG Bulletin. 1983. 67(7): 1176-1191

Li G Z, Cheng T J, Tang Y P, et al. Petroleum geological significance of physical adsorption of hydrocarbon in surface soil. Oil \& Gas Geology. 2006. 27(5): 689-695 (in Chinese)

Liu W H, Xu Y C and Lei H Y. Bio-thermocatalytic transitional zone gas and its genetic indicators. Bulletin of Mineralogy, Petrology and Geochemistry. 1997. 16(1): 51-54 (in Chinese)

Miao Z Y, Chen J F, Guo J J, et al. Geochemistical characteristics of butane gas in the Tarim Basin. Journal of China University of Mining \& Technology. 2011. 40(4): 592-597 (in Chinese)

Prinzhofer A and Pernaton É. Isotopically light methane in natural gas: bacterial imprint or diffusive fractionation? Chemical Geology. 1997.
142(3-4): 193-200

Shi J A, Sun X J, Wang J P, et al. Physical simulating experiment of natural gas migration and its characteristics of composition differentiation and carbon isotope fractionation. Petroleum Geology \& Experiment. 2005. 27(3): 293-298 (in Chinese)

Tinivella U, Accaino F and Vedova B D. Gas hydrates and active mud volcanism on the South Shetland continental margin, Antarctic Peninsula. Geo-Marine Letters. 2008. 28(2): 97-106

Wang T D and Yang Y C. Geological chromatograph and natural gas migration in upper Triassic in the central part of Sichuan. Natural Gas Industry. 1986. 6(1): 15-20 (in Chinese)

Wang Y P, Zhao C Y, Wang Z Y, et al. Identification of marine natural gases with different origin sources. Science in China (Series D). 2008. 51(Supp I): 148-164

Xu Y C. Genetic Theory and Application of Natural Gas. Beijing: Science Press. 1994 (in Chinese)

Xu Y C, Shen P, Liu W H, et al. A new natural gas genetic type-Biothermocatalytic transitional zone gases. Science in China (Series B). 1990. (9): 975-980 (in Chinese)

Yang W W, Liu G D, Gong Y J, et al. Microbial alteration of natural gas in the Xinglongtai field of the Bohai Bay Basin, China. Chinese Journal of Geochemistry. 2012. 31(1): 55-63

Zhang J J, Zhao Z, Duan A J, et al. Study on adsorption and diffusion of $\mathrm{C}_{4}$ alkanes in ZSM-5 and Y zeolites. Industrial Catalysis. 2007. 15(9): 5-9 (in Chinese)

Zhang S C, Zhao W Z, Wang F Y, et al. Paleozoic oil cracking gas accumulation history from eastern part of the Tarim Basin-a case study of the YN2 gas reservoir. Natural Gas Geoscience. 2004. 15(5): 441-451 (in Chinese)

Zhang X B, Hu Y, Ma L Y, et al. Carbon isotope characteristics, origin and distribution of the natural gases from the Tertiary salty lacustrine facies in the west depression region in the Qaidam Basin. Science in China (Series D). 2003. 46(7): 694-707

(Edited by Hao Jie) 